\title{
Influence of effective microorganisms on pikeperch nonspecific humoral immunity, general condition, and development
}

\author{
Elżbieta Terech-Majewska, Joanna Pajdak-Czaus, Edyta Kaczorek-Łukowska, \\ Maciej Rożyński, Zdzisław Zakęś, Agata Kowalska, Krzysztof Kazuń, Andrzej K. Siwicki
}

Received - 02 June 2021/Accepted - 10 May 2021. Published online: 30 June 2021; @Inland Fisheries Institute in Olsztyn, Poland Citation: Terech-Majewska. E., Pajdak-Czaus, J., Kaczorek-Łukowska, E., Rożyński, M., Zakęś, Z., Kowalska, A., Kazuń, K., Siwicki, A. K. (2021). Influence of effective microorganisms on pikeperch nonspecific humoral immunity, general condition, and development. Fisheries Aquatic \& Life, 29, 80-87.

\begin{abstract}
Products containing effective microorganisms $\left(\mathrm{EM}^{\mathrm{TM}}\right)$ use microorganisms to work in the environment in which they are applied. $\mathrm{EM}^{\mathrm{TM}}$ is used in many countries worldwide, mainly in agriculture, including in aquaculture, and in environmental protection. Fish farmers use these products to stimulate effective growth and conditioning and as immunity enhancers. The aim of the study was to evaluate the effect of $\mathrm{EM}^{\mathrm{TM}}$ Probiotyk (Greenland, Poland) on the development of humoral non-specific resistance in pikeperch (Sander lucioperca) in the initial stage of rearing in recirculating aquaculture systems (RAS). The experimental diet was administered for 28 days with $0 \%$ (control group), $2 \%$, and $4 \% \mathrm{EM}^{\mathrm{TM}}$ supplementation. The results from the humoral parameters (Lys, TP, Ig) showed no statistical differences. The only statistically significant difference was
\end{abstract}

E. Terech-Majewska, J. Pajdak-Czaus [ $\left.\Xi^{\circ}\right]$

Department of Epizootiology, Faculty of Veterinary Medicine,

University of Warmia and Mazury in Olsztyn, Poland

E-mail: joanna.pajdak@uwm.edu.pl

E. Kaczorek-Łukowska

Department of Microbiology and Immunology, Faculty of Veterinary

Medicine, University of Warmia and Mazury in Olsztyn, Poland

M. Rożyński, Z. Zakęś, A. Kowalska

Department of Aquaculture, Stanisław Sakowicz Institute of Inland

Fisheries, Olsztyn, Poland

K. Kazuń, A. K. Siwicki

Department of Fish Pathology and Immunology, Stanisław Sakowicz

Institute of Inland Fisheries, Olsztyn, Poland noted in Cer for the 4\% group. Non-specific humoral-mediated immunity in fish plays a key role in defense against damaging factors. Pikeperch is a fish used for restocking open waters, where fish can be subjected to agrotechnical treatments, including $\mathrm{EM}^{\mathrm{TM}}$. The results permitted estimating the potential risks of using $\mathrm{EM}^{\mathrm{TM}}$ in aquaculture.

Keywords: EM ${ }^{\mathrm{TM}}$ Probiotic, Sander lucioperca, humoral defense mechanism

\section{Introduction}

Aquaculture is a highly dynamically developing branch of agriculture. Production of various fish species has been progressively intensified, and fish fry and fingerling rearing technologies under controlled conditions have been developed for different fish species, including pikeperch (Sander lucioperca). Rearing fish in controlled environments entails implementing adequate breeding and biosecurity conditions. Certain prophylactic measures are necessary such as vaccinations, the use of probiotics, and feed supplementation with immunomodulatory additives (Kowalska et al. 2012, Magnadottir 2010, Mishra et al. 2017, Terech-Majewska et al. 2018a). 
Administering microbiological products, or probiotics, is an approved immunomodulation approach used in the rearing of endothermic and ectothermic animals, including aquaculture animals (Newaj-Fyzul and Austin 2015, Sokół et al. 2017, Van Vliet et al. 2006, Wang et al. 2008). Probiotic products are mostly administered to stimulate the response of the congenital immune systems of fishes at different stages of their development. Another motivation for using probiotics is their beneficial effect on adaptability parameters and non-specific cellular and hormonal immunity (Terech-Majewska 2016, Terech-Majewska et al. 2016). Since they are always available, non-specific immune mechanisms provide fundamental protection that helps maintain good health continually. In contrast, acquired immune mechanisms take time to develop in response to specific stimuli. Probiotics can be useful at different stages of fish rearing, and especially during transient stages, i.e. sexual maturation, spawning, sorting, or transfer to a new environment (Magnadottir 2010, Newaj-Fyzul and Austin 2015). It is also believed that probiotics improve appetite and stimulate animal weight gain (Brzozowski et al. 2013, Zorriehzahra et al. 2016). Probiotic treatments are reported to improve cellular and humoral resistance parameters (Newaj-Fyzul and Austin 2015), and they also demonstrate beneficial effects as vaccine adjuvants (Magnadottir 2010).

Numerous complex microbiological products have been developed for use in pisciculture, e.g., Alibio Bacillus sp. Suarez Company (Mexico), Bactocell PA10 Pedicoccus acidilactici Lallemand Nutrition Company (France), Biogen B. subtilis, B. liheniformes (South Africa), Biostart Bacillus sp. and Paenobacillus sp. BioStart Company (New Zealand), Biostart HB-2 Bacillus liheniformes Biostart (New Zealand), BioZyme Aqua Bacillus subtilis Aquarium Products (the USA), BGY35 Saccharomyces cerevisiae Emmert Company (the USA), Cernivet LBC Bacillus toyoi Cerbiot (Swizterland), SanoCare Bacillus sp. INVE Aquaculture (Belgium), SanoGuard Bacillus sp. INVE Aquaculture, (Belgium), SanoLife Bacillus sp. INVE Aquaculture, (Belgium) (Tang et al. 2016). The original effective microorganism products were developed based on Theruo Higa's research in the 1980s. These products can consist of more than 80 species of microorganisms with different functions that are suitable for both human and animal consumption. The microorganisms used in $\mathrm{EM}^{\mathrm{TM}}$ products act through mutual biological synergy, and those included in probiotics include lactic acid bacteria (Lactobacillus plantarum, L. casei, Streptococcus lactis), photosynthesizing bacteria (Rhodopseudomonas palustrus, Rhodobacter apaeroides), yeasts (Saccharomyces cerevisiae, Candida utilis), actinomycetes (Streptomyces albus, S. gipseus, Actinomycetes), and fermenting fungi (Aspergillus oryzae, Penicillum sp., Mucor hiemalis) (Condor et al. 2007, Mustafa et al. 2011, Rapatsa and Moyo 2013, Qui et al. 2009). $\mathrm{EM}^{\mathrm{TM}}$ products are applied in agriculture (soil remediation, plant production, agriculture, food processing, storage), environmental protection (e.g., water revitalization, water body and watercourse purification), municipal waste management (wastewater treatment, landfills, composting plants), households (home, garden, cesspool), human and veterinary medicine, fish farming, and many other areas. They can also serve as additives to feeds that can improve fodder, and new applications are being investigated, e.g., lake restoration (Sitarek et al. 2016).

Every new factor introduced into fish rearing must be verified in terms of its influence on nonspecific and specific immunity mechanisms since the efficiency of these systems often determine fish survival, and they can also improve feed digestibility and availability, e.g. in feeds with added plants (Thiam et al. 2015). New studies are constantly being undertaken in controlled environments. Considering the complex nature of $\mathrm{EM}^{\mathrm{TM}}$ products, the effects of these probiotics must be verified in fish of different species that are reared using different technologies taking into account diverse environmental conditions (Verschuere et al. 2000). When designing technologies for the rearing and farming of new fish species, efforts are made to determine species-specific responses to the various factors present at all stages of technological cycles. Pikeperch is considered to be a difficult species to cultivate in aquaculture because 
of its biology and low degree of domestication and its relatively low survival rates, especially in larval stages (Bregnballe 2015, Siwicki et al. 2003, Wang et al. 2017). This species can be farmed in earthen ponds and in recirculating aquaculture systems (RAS), which provides opportunities to conduct spawning and rearing outside of the breeding season. Good breeding results can be obtained in polyculture with carp (Cyprinus carpio L.) and sterlet (Acipenser ruthenus L.) (Kozlowski et al. 2014, Wang et al. 2017). Current knowledge indicates that pikeperch can be reared at various intensities, which encourages studies aimed at developing and improving methods employed to protect this species from diseases through the use of various feed additives (Siwicki et al. 2006, Siwicki et al. 2009). Summer and fall juvenile fry and fingerlings and adult pikeperch (commercial selects and spawners) are all produced (Zakęś 2017). During the rearing cycle, pikeperch must be sorted by size frequently to mitigate negative stress responses, or distress, and to avoid greater risks of exposure to environmental and pathogenic conditions, e.g. Aeromonas sp., Pseudomonas sp. (Terech-Majewska, data unpublished).

The aim of the current study was to evaluate the effects of $\mathrm{EM}^{\mathrm{TM}}$ Probiotyk (Greenland, Poland) administered as a feed supplement on the mechanisms of nonspecific humoral-mediated immunity, overall condition, and the development of pikeperch reared in experimental RAS.

\section{Material and methods}

The study focused on $\mathrm{EM}^{\mathrm{TM}}$ Probiotyk. The fish were reared in experimental facilities at the Department of Aquaculture of the Institute of Inland Fisheries in Olsztyn. The experiments were performed on juvenile pikeperch with initial body weights of $3.21 \mathrm{~g} \mathrm{(} \pm$ $0.51 \mathrm{~g})$ and body lengths 1.c. of $6.38 \mathrm{~cm}( \pm 0.33 \mathrm{~cm})$. A total of 1,170 specimens were examined. The fish were divided into three experimental groups, each comprising 390 fish. Each group (in three replicates with 130 fish in each tank) was kept in rearing tanks with volumes of $0.2 \mathrm{~m}^{3}$, which corresponded to approximately $2 \mathrm{~kg} \mathrm{~m}^{-3}$.

During the controlled rearing period, water parameters were monitored that are crucial for proper fish growth and immunity development, such as water temperature, oxygen saturation, total ammonia nitrogen $\left(\mathrm{CAA}=\mathrm{NH}_{4}{ }^{+}-\mathrm{N}+\mathrm{NH}_{3}-\mathrm{N}, \mathrm{mg} \mathrm{L}^{-1}\right)$, nitrite levels $\left(\mathrm{NO}_{2}-\mathrm{N}, \mathrm{mg} \mathrm{L}^{-1}\right)$, and $\mathrm{pH}$. The average water temperature during the experiments was $22.9 \pm$ $0.4^{\circ} \mathrm{C}$. The oxygen concentration in water at the outflow from the tanks never fell below $7.3 \mathrm{mg} \mathrm{O}_{2} \mathrm{~L}^{-1}$ (84\% saturation). The concentrations of ammonia and nitrites at the outflow did not exceed $0.2 \mathrm{mg}$ $\mathrm{CAA} \mathrm{L}^{-1}$ or $0.03 \mathrm{mg} \mathrm{NO}_{2}-\mathrm{N} \mathrm{L}^{-1}$. The $\mathrm{pH}$ at the outflow was within the range of 8.1-8.4.

The experimental feed was prepared using the commercial trout feed Aller Performa EX 2GR (AllerAqua, Denmark) with the following basic chemical composition: protein (54\%), crude fat (15\%), carbohydrates (13\%), cellulose $(1.5 \%)$, ash (8.5\%), and digestible energy $19.1 \mathrm{MJ} \mathrm{kg}^{-1}$. The feed was supplemented with $\mathrm{EM}^{\mathrm{TM}}$ Probiotyk in two con-

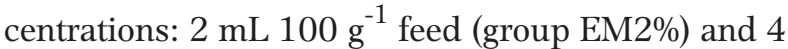
$\mathrm{mL} 100 \mathrm{~g}^{-1}$ (group EM4\%) following the procedure described in Terech-Majewska et al. (2018). The control group (group C) was composed of fish fed the basic feed with $20 \mathrm{~mL}$ water added per $400 \mathrm{~g}$ feed. The fish were fed the experimental feeds for 28 days, but they received standard feed until sample collection. The duration of rearing after the conclusion of the period in which the $\mathrm{EM}^{\mathrm{TM}}$ experimental feeds were provided was 56 days, so the total length of the experiment was 84 days.

Feeds were delivered to the fish by automated belt feeders (Fischtechnik GmbH, Germany) for $18 \mathrm{~h}$ $d^{-1}$ (09:00 - 03:00). The daily feed ration was determined weekly and was reduced from $3.5 \%$ (first two weeks), to $2.5 \%$ (from weeks 3 to 8 of rearing), and then to $2 \%$ of the fish stock biomass until the end of the rearing cycle. During rearing, fish growth was assessed by body weight (expressed in $\mathrm{g}$ ) at the beginning of the experiment and after 28, 56, and 84 days of the experiment.

Following the feed test, the fish (40 individuals from each experimental group) were transferred to 
Table 1

Parameters of the growth of pikeperch fed commercial feed (group C) and feed supplemented with a 2 or $4 \%$ addition of effective microorganisms (EM ${ }^{\mathrm{TM}}$ Probiotyk, Greenland, Poland)

\begin{tabular}{|c|c|c|c|}
\hline \multirow[b]{3}{*}{ Time } & \multicolumn{3}{|c|}{ Experimental groups } \\
\hline & \multicolumn{3}{|l|}{ Body weight (g) } \\
\hline & Group C & Group EM2\% & Group EM4\% \\
\hline Initial $(n=9)$ & $3.21(\mathrm{SD} 0.51)$ & $3.21(\mathrm{SD} 0.51)$ & $3.21(\mathrm{SD} 0.51)$ \\
\hline After 28 days $(n=9)$ & 9.43 (SD 3.15) & 9.57 (SD 3.19) & $9.64(\mathrm{SD} 2.64)$ \\
\hline After 56 days $(n=9)$ & 20.51 (SD 5.34) & 19.06 (SD 5.49) & 19.67 (SD 4.88) \\
\hline After 84 days $(n=9)$ & $56.00(\mathrm{SD} 6.4)$ & 56.67 (SD 6.63) & $53.14(\mathrm{SD} 5.76)$ \\
\hline Multiplication of growth from initial to final values & X 17.45 & X 17.65 & $\mathrm{X} 16.55$ \\
\hline
\end{tabular}

No statistically significant differences were noted in any of the experimental groups (ANOVA, Bonferroni test, $\mathrm{P}>0.05$ )

experimental tanks located in a facility of the Chair of Epizootiology, Faculty of Veterinary Medicine, University of Warmia and Mazury in Olsztyn. The fish were transported in polyethylene bags (20 L water + 20 L oxygen) 56 days after the conclusion of the period in which they were fed the experimental feeds (Zakęś 2017). Blood samples were drawn from the caudal veins of nine fish from each experimental group. Blood serum was obtained from these samples for immunological assays. Prior to manipulation, the fish were anesthetized with Propiscin (IFI Olsztyn) at a concentration of $1 \mathrm{~mL} \mathrm{~L}^{-1}$ water, and were kept in aerated plastic containers until the experimental procedures began (Kazuń and Siwicki 2001). Blood was centrifuged for 10 minutes at $4^{\circ} \mathrm{C}$ at a speed of $8000 \mathrm{x}$ rotations. Selected parameters of non-specific humoral resistance were assessed in serum samples. The activity of lysozyme (Lys) in serum was determined according to the method described in and modified by Siwicki and Anderson (1993) with the turbidimetric method using the bacteria Micrococcus lysodeikticus (Sigma). Total protein content (TP) was determined spectrophotometrically with the biuret method (Diagnostic Kits - Protein Total Reagents; Sigma) according to the manufacturer's recommendations. The level of immunoglobulins (Ig) was determined with spectrophotometry using the biuret method (Diagnostic Kits - Protein Total Reagents - Sigma) and polyethylene glycol $10000 \mathrm{kDa}$
(Sigma) (Siwicki and Anderson 1993). The level of ceruloplasmin (Cer) was determined with spectrophotometry according to a method adapted for fish experiments and described by Siwicki et al. (2010a). The hepatosomatic index (HSI) was calculated with the following formula: HSI $(\%)=100 \times$ $\left(\mathrm{ML} \times \mathrm{WB}^{-1}\right)$, where $\mathrm{ML}$ - liver weight $( \pm \mathrm{x}, \mathrm{x} \mathrm{g}), \mathrm{WB}$ - body weight $( \pm x, x g)$. The spleen somatic index was determined as follows: SSI $(\%)=100 \times(\mathrm{MS} \times$ $\left.\mathrm{WB}^{-1}\right)$ - where MS - weight of spleen $( \pm \mathrm{x}, \mathrm{x} \mathrm{g})$.

The results were analyzed statistically, and mean values and standard deviation (SD) were calculated using Statistica for Windows 7.1 (Stat-Soft, Inc 2004), while the significance of differences at ${ }^{*} \mathrm{P}<$ $0.05,{ }^{*} \mathrm{P} \leq 0.01$, and ${ }^{*} * \mathrm{P} \leq 0.001$ was assessed with one-factor analysis of variance (ANOVA) and multi-factor analysis using the Bonferroni test.

\section{Results}

The analysis of fish growth parameters over the course of the experiment did not differ significantly statistically (Table 1). The final body weights of the fish in the experimental groups were: $56 \mathrm{~g}$ (group C, \pm 6.4 ), $56.67 \mathrm{~g}$ (group EM2\%, \pm 6.63 ), and $53.14 \mathrm{~g}$ (group EM4\%, \pm 5.76 ). Differences in the values of the immunity parameters analyzed, i.e., Lys, TP, and Ig, among the groups were not statistically significant 
Table 2

Values of parameters of non-specific humoral resistance in pikeperch (Sander lucioperca), following the supplementation with $2 \%$ or $4 \%$ doses of $\mathrm{EM}^{\mathrm{TM}}$ Probiotyk (Greenland, Poland)

\begin{tabular}{llll}
\hline \hline Immunological parameters & Control $\mathrm{n}=9$ & $\mathrm{EM} \% \mathrm{n}=9$ & EM4\% $\mathrm{n}=9$ \\
\hline \hline Lysozyme Lys $\left(\mathrm{mg} \mathrm{L}^{-1}\right)$ & $25.1 \pm 8.7$ & $31.2 \pm 12$ & $28.4 \pm 6.7$ \\
Ceruloplasmin Cer (IU) & $64.8 \pm 3.4$ & $60.5 \pm 9.5$ & $54.8 \pm 8.1^{*}$ \\
Total protein TP $\left(\mathrm{g} \mathrm{L}^{-1}\right)$ & $31.7 \pm 4.9$ & $32 \pm 2$ & $31.1 \pm 2.2$ \\
Total Immunoglobulins TIg $\left(\mathrm{g} \mathrm{L}^{-1}\right)$ & $6.8 \pm 2$ & $6.2 \pm 1.3$ & $5.9 \pm 1.3$ \\
Average body weight (g) & $56 \pm 6.4$ & $56.67 \pm 6.63$ & $53.143 \pm 5.76$ \\
Hepatosomatic Index HSI & 1.64 & 1.45 & 1.61 \\
Spleen somatic Index SSI & 2.33 & 1.34 & 1.77 \\
\hline
\end{tabular}

${ }^{*}$ Statistically significant (Anova, Bonferroni test, ${ }^{*} \mathrm{P}>0.05$ )

(Table 2). Statistically significant differences, however, were determined in the level of Cer between groups $\mathrm{C}$ and $\mathrm{EM} 4 \%(\mathrm{P}<0.05)$. Nevertheless, after the adaptation period, the fish from group EM2\% were the weakest and died presenting nonspecific clinical symptoms and extensive skin lesions. Group $\mathrm{EM}$ \% had the lowest survival rate, while the Lys and $\mathrm{TP}$ values were higher than those in the control group, and the Cer and Ig values were moderate. Lys activity was the highest in the fish from group EM2\%, in which it reached $31.2 \mathrm{mg} \mathrm{L}^{-1}(\mathrm{SD} \pm 12.0)$. The lowest Cer, TP, and Ig values were determined in group EM4\%. Lys activity among the fish from this group was moderate relative to group C. The HSI value ranged from 1.64\% (group C) to 1.61\% (group EM4\%) and 1.45\% (group EM2\%). The SSI values oscillated around 2.33\% (group C), 1.77\% (group EM4\%), and 1.34\% (group EM2\%). Fish survival at the end of the experiment was 90\% (C and EM4\%) and $74.38 \%$ (EM2\%).

\section{Discussion}

The results of the current experiment presented herein originated from the assessment of the influence of $\mathrm{EM}^{\mathrm{TM}}$ Probiotyk on humoral mechanisms of nonspecific immunity that varied depending on the dose of the product. By definition, probiotics and prebiotics are expected to demonstrate anti-infective, immunostimulating activity. $\mathrm{EM}^{\mathrm{TM}}$ products contain various species of probiotic microorganisms, which can elicit multidirectional effects depending on the fish species and rearing technology. Cieśla (2016) demonstrated the beneficial influence on nonspecific humoral immunity in C2 carp in a study that indicated the positive impact of an $\mathrm{EM}^{\mathrm{TM}}$ feed additive on the volume of fish production per ha, the general condition of fish, and their resistance. In addition, the group that received $\mathrm{EM}^{\mathrm{TM}}$ had the lowest degree of infestation with parasites such as Trichodina, Chilodonella, Epistylis, Dactylogyrus, Botriocephalus, and leaches in comparison to fish fed feeds without $\mathrm{EM}^{\mathrm{TM}}$.

Probiotics are thought to stabilize populations of microorganisms and enzymatic activity in the digestive tract, as a result of which they have a positive effect on the growth and development of animals. $\mathrm{EM}^{\mathrm{TM}}$ Probiotyk fully satisfies requirements for probiotic supplements, and it is possible to use it in aquaculture under various climatic conditions. In fish farming, it can be used in two ways: added to water in order to accelerate the decomposition of the organic matter that accumulates in it, or as a dietary supplement added to fish feeds to optimize digestion, the immune system, and infection resistance. These effects were confirmed in a study conducted on rainbow trout fingerlings, in which the average body weight (BW) of control fish $(51.75 \mathrm{~g})$ was $2 \%$ lower than that of fish from the $\mathrm{EM}^{\mathrm{TM}}$ group $(52.79 \mathrm{~g})$. The differences persisted throughout the experiment, which was confirmed by measurements taken 30 days after the conclusion of 
supplementation with the EMTM product. The average BW of the fish from group C (control) $(83.1 \mathrm{~g}$ ) was 9.7\% lower than that of fish from the $\mathrm{EM}^{\mathrm{TM}}$ group (91.16 g; Terech-Majewska 2016).

The experimental treatments reported on in this paper employed approved nonspecific resistance markers, i.e., Lys, Cer, TP, and Ig (Magnadottir 2010). Lys activity is one of the key indicators of nonspecific resistance, especially against bacterial infections caused by $A$. salmonicida and $A$. hydrophila (Ellis 1999). Lysozyme is a cation enzyme that targets the b-1,4-glycoside linkages between and in the peptidoglycan of the cell walls of bacteria. This enables the lysis of some Gram-negative bacteria (Balcazar et al. 2007). The research results reported here show that the group with the highest activity of this enzyme was group $2 \% \mathrm{EM}\left(31.2 \mathrm{mg} \mathrm{L}^{-1} \pm 12.0\right)$, but the difference was not statistically significant relative to the control.

Cer is a protein synthesized in correlation with liver development. It is a multi-task protein, and its level in blood serum can be determined by the efficiency of liver immune function, its metabolic activity, and, possibly, the extent of damage to this organ. Cer has been demonstrated to play a significant role in the prevention of diseases and inflammatory conditions, in response to acute phases or in early immunological protection (Das and Sahoo 2018). Genes encoding Cer are present in many fish tissues including in the spleen, brain, gills, stomach, intestines, skin, kidneys, eyes, and heart. However, it is difficult to ascribe unequivocally the activity of this protein to specific types of cells and tissues. Assessing Cer levels in the serum serves as a parameter for monitoring fish resistance status (Das and Sahoo 2014). It is also an important parameter for evaluating fish the health during trials concerning immunomodulation. The indicators of humoral resistance in another study by Terech-Majewska et al. (2016) conducted on rainbow trout were higher in the EMTM group than in the control group. Increases in Cer levels after 30 days of $1 \%$ feed supplementation were statistically significant $(\mathrm{P}<0.01)$. In this present study on pikeperch, decreases in Cer levels were noted in groups $2 \% \mathrm{EM}$ and $4 \% \mathrm{EM}$, and the difference relative to the control was statistically significant for group 4\%EM $(\mathrm{P}<0.05$; Table 2$)$.

In the current study the assessment of the influence on non-specific resistance mechanisms was based on humoral parameters, the values of which depend on the functioning of organs such as the spleen, the liver, and the head kidney. The levels of these indicators depend on the fish species, age, physiological condition, type of feed supplied, stress, and the degree of damage to organs (Kowalska et al. 2012, Siwicki et al. 2010a, b). The HSI and SSI levels confirmed humoral parameter differences. The lowest HSI (1.45\%) and SSI (1.34\%) values were noted in group EM2\%, where the lowest Cer activity (60.5 IU \pm 9.5$)$ and the lowest IG level (6.2 $\mathrm{g} \mathrm{L}^{-1} \pm 1.3$ ) were determined (Table 1). This indirectly confirmed some liver (Cer and HIS) and spleen (Ig and SSI) deficiencies. These conclusions are supported by the results of liver and spleen histopathological assays conducted by Terech-Majewska et al. (2016, 2018b).

\section{Conclusions}

The following conclusions were drawn based on the research results on the effect of $\mathrm{EM}^{\mathrm{TM}}$ on nonspecific humoral resistance in the early stage of rearing pikeperch fingerlings:

- the addition of the complex microbiological product $\mathrm{EM}^{\mathrm{TM}}$ Probiotyk in amounts of $2 \%$ and $4 \%$ of the feed and supplied for 28 days did not impair fish condition or survival during 84 days of rearing juvenile pikeperch in RAS (including 56 days after the experimental feed supplemented with $\mathrm{EM}^{\mathrm{TM}}$ feed administration was discontinued);

- $\mathrm{EM}^{\mathrm{TM}}$ Probiotyk had different impacts on resistance mechanisms depending on the dose administered;

- at a dose of 4\%, EM Probiotyk caused decreased levels of Cer, TP, Ig, and average body weight, while increasing Lys levels compared to the parameters above in the fish from group $\mathrm{C}$; 
- EM ${ }^{\mathrm{TM}}$ Probiotyk caused decreases in the HSI and SSI values in fish from groups $2 \% \mathrm{EM}$ and $4 \% \mathrm{EM}$ in comparison to group C.

The results presented above should be classified as findings indicating the negative effects of $\mathrm{EM}^{\mathrm{TM}}$ since this research proved that EMTM-based products can have an adverse influence on the general condition of fish, immunological response, and anti-infective resistance. Pikeperch is stocked into open waters, where they are subjected to agrotechnical treatments including $\mathrm{EM}^{\mathrm{TM}}$. This, alongside the current results, suggests that further studies are necessary to reliably assess what the impact is of such complex products on various species and environmental conditions.

Author contributions. E.T-M.: study concept and design, conducting the experiment, sampling, manuscript preparation. J. P-Cz.: corresponding author, conducting the experiment, manuscript preparation. E.K-Ł.: statistical analysis. M.R.: conducting the experiment, statistical analysis. Z.Z.: study concept and design, manuscript preparation. A.K.: performing laboratory tests. K.K.: performing laboratory tests. A.K.S.: analysis and interpretation of research results.

\section{ORCID iD}

Elżbieta Terech-Majewska (iD) 0000-0001-9093-0049

Joanna Pajdak-Czaus (iD 0000-0003-2289-2241

\section{References}

Balcázar, J. L., De Blas, I., Ruiz-Zarzuela, I., Vendrell, D., Gironés, O., Muzquiz, J. L. (2007). Enhancement of the immune response and protection induced by probiotic lactic acid bacteria against furunculosis in rainbow trout (Oncorhynchus mykiss). FEMS Immunology \& Medical Microbiology, 51(1), 185-193.

Bregnballe, J. (2015). A guide to recirculation aquaculture an introduction to the environmentally friendly and highly productive closed fish farming system. In: Food and Agriculture Organisation the United Nations (FAO) and Eurofish, 43.

Brzozowski, M., Rekiel, A., Więcek, J., Gajewska, J. (2013). Evaluation of a prophylactic program based upon effective microorganisms in fattening of pigs. Medycyna Weterynaryjna 69, 248-251 (in Polish).
Cieśla, M. (2016). Research report, access http://pir.sggw.pl/karp.html

Golec, A. F. C., Pérez, P. G., Lokare, C. (2007). Effective microorganisms: myth or reality? Revista Peruana de Biología, 14(2), 315-319.

Das, S., Sahoo, P. K. (2014). Markers for selection of disease resistance in fish: a review. Aquaculture International, 22(6), 1793-1812.

Das, S., Sahoo, P. K. (2018). Ceruloplasmin, a moonlighting protein in fish. Fish \& Shellfish Immunology, 82, 460-468.

Ellis, A. E. (1999). Immunity to bacteria in fish. Fish \& Shellfish Immunology, 9(4), 291-308.

Kazuń, K., Siwicki, A. K. (2001). Propiscin-a safe new anaesthetic for fish. Archives of Polish Fisheries, 9, 183-190.

Kowalska, A., Zakęś, Z., Siwicki, A. K., Jankowska, B., Jarmołowicz, S., Demska-Zakęś, K. (2012). Impact of diets with different proportions of linseed and sunflower oils on the growth, liver histology, immunological and chemical blood parameters, and proximate composition of pikeperch Sander lucioperca (L.). Fish Physiology and Biochemistry, 38(2), 375-388.

Kozłowski, M., Szczepkowski, M., Wunderlich, K., Szczepkowska, B., Piotrowska, I. (2014). Polyculture of juvenile pikeperch (Sander lucioperca (L.)) and sterlet (Acipenser ruthenus L.) in a recirculating system. . Archives of Polish Fisheries, 22(4), 237-242.

Magnadottir, B. (2010). Immunological control of fish diseases. Marine Biotechnology, 12(4), 361-379.

Mishra, S. S., Das, R., Das, B. K., Choudhary, P., Rathod, R., Giri, B. S., ... Swain, P. (2017). Status of Aqua-medicines, drugs and chemicals use in India: A Survey Re-port. Journal Aquactic Fisheries, 1(004).

Mustafa Al. Bakri, M.A., Hadi Ma Radzi, A., Akmal Mohamad, N.S., Zainul, S.K., Diyana, N.Y. (2011). Production of effective microorganism using halal-based sources: A review. African Journal of Biotechnology, 10, 18649-18652.

Newaj-Fyzul, A., Austin, B. (2015). Probiotics, immunostimulants, plant products and oral vaccines, and their role as feed supplements in the control of bacterial fish diseases. Journal of Fish Diseases, 38(11), 937-955.

Qi, Z., Zhang, X. H., Boon, N., Bossier, P. (2009). Probiotics in aquaculture of China-current state, problems and prospect. Aquaculture, 290(1-2), 15-21.

Rapatsa, M. M., Moyo, N. A. G. (2013). Haematological, histological and growth characteristics of Oreochromis mossambicus exposed to Effective Microorganisms in organically manured aquadams. Asian Journal of Animal and Veterinary Advances, 8(7), 852-862.

Sitarek, M., Napiórkowska-Krzebietke, A., Mazur, R., Czarnecki, B., Pyka, J.P., Stawecki, K., Olech, M., Sołtysiak, S., Kapusta, A. (2016). Application of effective Microorganisms technology as a lake restoration tool - 
a case study of Muchawka reservoirs. Journal of Elementology, 22, 529-543.

Siwicki, A.K., Anderson, D.P. (1993). Nonspecific defense mechanisms assay in fish. In: disease diagnosis and prevention's methods. FAO-Project GCP/INT/526/JPN, IFI Olsztyn, 105-112.

Siwicki, A.K., Zakęś, Z., Trapkowska, S., Terech-Majewska, E., Czerniak, S., Głąbski, E., Kazuń, K. (2003). Nonspecific cellular and humoral defense mechanisms in pikeperch (Sander lucioperca) grown in a intensive system of culture. Archives of Polish Fisheries, 11, 207-212.

Siwicki, A.K., Zakęś, Z., Fuller, J.C., Nissen, S., Trapkowska, S., Głabski, E., Kowalska, A., Kazuń, K., Terech-Majewska, E. (2006). Influence of $\beta$ - hydroksy- $\beta$ methylbutyrate on nonspecific humoral defense mechanisms and protection against furunculosis in pikeperch (Sander lucioperc). Aquaculture Research, 37, 127-131.

Siwicki, A.K., Zakęś, Z., Terech-Majewska, E., Kowalska, A., Małaczewska, J. (2009). Supplementing the feed of pikeperch Sander lucioperca (L). with MacroGard and its influence on nonspecific cellular and humoral defense mechanism, Aquaculture Research, 40, 405-411.

Siwicki, A. K., Terech-Majewska, E., Grudniewska, J., Malaczewska, J., Kazun, K., Lepa, A. (2010). Influence of deltamethrin on nonspecific cellular and humoral defense mechanisms in rainbow trout (Oncorhynchus mykiss). Environmental Toxicology and Chemistry: An International Journal, 29(3), 489-491.

Siwicki, A.K., Kazuń, K., Głabski, E., Terech-Majewska, E. (2010b). Formation of non-specific humoral immunity in three lines of carp females reared in Poland. Komunikaty Rybackie, 3, 608. (in Polish).

Sokół, R., Gesek, M., Raś-Noryńska, M., Michalczyk, M., Koziatek-Sadłowska, S. (2017). Influence of effective microorganisms on selected serum biochemical parameters in Japanese quails infected with Cryptosporidium parvum. Medycyna Weterynaryjna, 73, 556-560.

Tang, J. Y., Dai, Y. X., Li, Y. M., Qin, J. G., Wang, Y. (2016). Can application of commercial microbial products improve fish growth and water quality in freshwater polyculture? North American Journal of Aquaculture, 78(2), 154-160.

Terech-Majewska, E. (2016). Improving disease prevention and treatment in controlled fish culture. Archives of Polish Fisheries, 24, 115-165.

Terech-Majewska, E., Grudniewska, J., Duchiewicz, K., Pajdak, J., Kaczorek, E., Schulz, P., Siwicki, A.K. (2016).
Effects of the EM product Probiotyk on non-specific immunity and anti-infective resistance in rainbow trout. Komunikaty Rybackie, 151, 10-15 (in Polish).

Terech-Majewska, E., Zakeś, Z., Kowalska, A., Siwicki, A.K., Szarek, J., Naumowicz, K. (2017). Influence of EM-probiotic on the morphology of the liver and gills in zander (Sander lucioperca). Proc. Joint European Congress of the ESVP and ECVP, The Bologna, 7-10.09.2016, Journal of Comparative Pathology, 1(156), 90.

Terech-Majewska, E., Kaczorek, E., Schulz, P., Zakeś, Z., Rożyński, M., Kowalska, A., Zembrzuska, M., Siwicki, A.K. (2018a). Influence of effective microorganisms on the non-specific cellular defense mechanisms of pikeperch. Medycyna Weterynaryjna, 74, 314-319.

Terech-Majewska E., Zakęś Z., Kowalska A., Siwicki A.K., Szarek J., Naumowicz K. (2018b). Influence of EM-probiotic on the morphology of the spleen in zander (Sander lucioperca). Proc. Joint European Congress of the ESVP and ECVP, The Lyon, 09. 2017, Journal of Comparative Pathology, 158, 146.

Thiam, S., Fall, J., Loum, A., Sabne, M., Diouf, M. (2015). Use of effective microorganisms (EM) in tilapia diets: Effects of growth performance and carcass composition. International Journal of Current Microbiology and Applied Science 4, 536-549.

Van Vliet, P. C. J., Bloem, J., De Goede, R. G. M. (2006). Microbial diversity, nitrogen loss and grass production after addition of Effective Micro-organisms ${ }^{\circledR}(\mathrm{EM})$ to slurry manure. Applied Soil Ecology, 32(2), 188-198.

Verschuere, L., Rombaut, G., Sorgeloos, P., Verstraete, W. (2000). Probiotic bacteria as biological control agents in aquaculture. Microbiology and Molecular Biology Reviews, 64(4), 655-671.

Wang, Y. B., Li, J. R., Lin, J. (2008). Probiotics in aquaculture: challenges and outlook. Aquaculture, 281(1-4), 1-4.

Wang, W., Sun, J., Liu, C., Xue, Z. (2017). Application of immunostimulants in aquaculture: current knowledge and future perspectives. Aquaculture Research, 48(1), $1-23$.

Zakęś, Z. (2017). Rearing and Breeding Pikeperch, IFI Olsztyn, Poland, 212 p. (in Polish).

Zorriehzahra, M. J., Delshad, S. T., Adel, M., Tiwari, R., Karthik, K., Dhama, K., Lazado, C. C. (2016). Probiotics as beneficial microbes in aquaculture: an update on their multiple modes of action: a review. Veterinary Quarterly, 36(4), 228-241. 